\title{
From Attention to Action: Entrepreneurial Networks and Performance of Women-Owned Enterprises: A Theoretical Review
}

\author{
Rachael Wambui ${ }^{1} \&$ Stephen Muathe ${ }^{2}$ \\ ${ }^{1}$ St. Paul's University, Kenya \\ ${ }^{2}$ Kenyatta University, Kenya \\ Correspondence: Rachael Wambui, St. Paul's University, Kenya. E-mail: wambui.gitonga@gmail.com
}

Received: December 2, 2020

Accepted: January 10, 2021

Online Published: January 28, 2021

doi:10.5539/ijbm.v16n2p82

URL: https://doi.org/10.5539/ijbm.v16n2p82

\begin{abstract}
In the contemporary business context, the firm's attractiveness and growth potential are demonstrated by its performance among other factors. Research has shown that women owned enterprises that utilize networking avenues to advance their businesses results in significant firm performance. Thus the objectives for the study were to discuss the key constructs of entrepreneurial networking and performance of women owned enterprises, to review theories that link entrepreneurial networking and performance, to recommend a conceptual framework that guides future studies on the highlighted knowledge gaps, and to recommend a methodological framework for future study. The study was anchored on Resource Based View, Dynamic Capability Theory, Social Capital, and Structural hole theory. The study was a desktop review of global theories related to entrepreneurial networking and performance in of women owned enterprises. Further, the empirical review was based on cross-sectional studies that explored entrepreneurial networking and performance of women owned enterprises. The studies reviewed were mainly conducted in the last ten years in developing nations in Africa and other parts of the world. The limitation of this study is that it only provides secondary data on existing studies on entrepreneurial networking and the performance of women owned enterprises. The findings indicated that these studies were convergent on the direct relationship between entrepreneurial networks and performance. A conceptual gap identified was the lack of moderating and mediating variables. The study recommended that future studies should incorporate, dynamic capabilities as a mediating variable and the business operating environment as moderating variable. Such studies should adopt explanatory non-experimental and descriptive research designs in collecting primary data which is crucial for filling the knowledge gaps identified in this study. Finally, a constructionist approach is proposed since the study seeks to add knowledge in the women entrepreneurship realm.
\end{abstract}

Keywords: business operating environment, dynamic capabilities, entrepreneurial networks, firm performance, resource based view, women owned enterprises

\section{Introduction}

Access to capital, a favorable regulatory framework, market penetration and access to raw materials are factors that contribute to better performance in an enterprise (Kariuki, 2015). Women entrepreneurs are prone to business growth challenges because they struggle to harness these factors to support the functions of their businesses. Studies indicate there is a link between entrepreneurial networking and firm performance (Todeva, 2011; Adamako et al., 2018; Agbim, 2018; Abbas et al., 2019). Morever, Urban (2019), draws attention to the notion that a firm's overall performance can be improved through networking since networking provides access to resources like financial access and market linkages that contribute to the well-being of a business. Women entrepreneurs that utilize these resources through networking stand improve their enterprises and gain a competitive advantage (Liu, Timothy \& Gao, 2010).

Additionally, the networking content matters in the overall performance of the enterprise. According to Ojotu, Tersoo and Kenneth (2019), businesses operate in interrelated network systems. These network relationships can both support and disadvantage the firm's performance in its pursuit to achieve its goals. As noted by Skokic (2015) firms are not solitary but are interconnected business systems. Furthermore, besides entrepreneurial incentives to form business networks, entrepreneurs should sufficiently consider the benefits to the performance of the business availed by networks (Skokic, 2015). 
Entrepreneurship has been shown to contribute to profitable work globally, and in so doing, women are major beneficiaries through the improvement of their livelihoods and financial status (Kariuki, 2015; Tawane \& Muathe, 2019). In a country like Kenya, women comprise the majority of citizenship, almost 51\%, (Trizer, 2019). These numbers can be of great economic value if more women are encouraged to actively participate in entrepreneurial activities that move the country towards economic prosperity. Women empowerment has led to the positive surge in more women engaging in entrepreneurial activities (Mulu-Mutuku et al., 2015). In this light, it becomes important for women to find other like-minded entrepreneurs and form connections that lead to gain for their enterprises. Entrepreneurial networking gives women entrepreneurs the opportunity obtain information on product innovations and market intelligence while building partnerships, and thereby improving the performance and sustainability of their businesses.

Research indicates that the women entrepreneurs in Kenya rarely engage in business networking yet this can improve their skills in operating successful enterprises. Those that do not exploit the available business networks disadvantage themselves from getting resources and information essential for survival and growth of their enterprises. In addition, women entrepreneurs who shun business networks inadvertently exclude themselves from global markets where they can explore new opportunities to expand their businesses (Kariuki, 2015).

\subsection{Statement of the Problem}

Business enterprises play a crucial role in the economy in terms of wealth and job creation and can be seen as the main drivers of economic growth. Hence, the survival and success of the entrepreneurial activities remains an important component to economic sustainability (Lange, Ottens, \& Taylor, 2000; Muathe, 2010; Muathe, Wawire \& Ofafa, 2013; Muathe \& Muraguri-Makau, 2020). Despite the efforts by the government towards entrepreneurial development, the performance of enterprises, and especially women owned enterprises, remains lackluster.

Past research by Omwenga, Mukulu and Kanali (2013) advanced three factors that can affect the performance of women entrepreneurs namely: financial and capital assistance, education and training, and entrepreneurial networking. However, the study assumed that these factors are only determinants of performance and ignored that there are mediating and moderating factors that could affect the nature of the relation.

Further studies by Oke (2013), Kariuki (2015) and Ojutu et al. (2019) concluded that SME's performance is affected by networking by way of increasing the business systems the enterprise is linked to. This allows the enterprise more opportunities for growth. The studies recommended that SMEs should have structures that allow them interact more with their business environments in order to enhance their networks. However, these studies assumed a direct relationship between the independent and dependent variables hence creating conceptual gaps.

\subsection{Objectives of the Study}

i. To discuss the key constructs of entrepreneurial networking and performance of women owned enterprises.

ii. To review theories that link entrepreneurial networking and performance.

iii. To recommend a conceptual framework that guides future studies on the highlighted knowledge gaps.

iv. To recommend a methodological framework for future study.

\section{Literature Review}

\subsection{Theoretical Review}

This section reviews theories underpinnings the study variables, the theories reviewed were Resource Based View, Dynamic Capability Theory, Social Capital Theory, and Structural Hole Theory.

\subsubsection{Resource Based View}

Edith Penrose (1914-1996), an American economist, is acclaimed for writing the book "The Theory of the Growth of the Firm" in 1959. Through this work, the Resource Based View (RBV) of the firm was birthed (Soni, 2015). RBV is a theoretical framework designed to explain why some businesses outperform others and remain sustainably competitive while utilizing the resources as opposed to their products (Wernerfelt, 1984). The RBV was developed to complement the industrial organization view with others like Bain (1968) and Porter (1980, 1985) being some of its main advancers. RBV contrasts with perspectives, such as Porter's (1985) theory of competitive advantage which focuses on the external environment as sources of threats and opportunities. The resource based view of the firm focuses on the internal organizational resources available to management (e.g. assets, information, human capacity, processes, knowledge, etc.) and dynamic capabilities as the determinants of competitive advantage (Muithya \& Muathe, 2020).

According to Porter (1985), competitive advantage gives business leverage over its competitors. He proposed 
that in order to advance the firm's performance, the strategic management should be concerned with facilitating sustainable competitive advantage. (Ganotakis 2010; Fatoki, 2011) used the resource based view to explain that human capital is important to entrepreneurship and contributes to the competitive advantage and performance for entrepreneurial firms. Further, (Elsenhardt \& Martin, 2000; Wiklund \& Shephered, 2004) used the resource based view to demonstrate how financial capital contributes the performance of enterprises. They supposed that firms need finances to obtain physical resources to take advantage of prevailing business opportunities.

The Resource Based View also assumes that firms can be conceptualized to have resources that can be divergently reallocated (Penrose, 1959; Wernerfelt, 1984; Amit \& Schoemaker, 1993). This led researchers to theorize that when firms have resources that are valuable, rare, inimitable, and non-substitutable (i.e., VRIN attributes), it is possible, with proper strategy implementation, to attain a competitive edge over competitors (Barney, 1991; Wernerfelt, 1984, 1995; Conner \& Prahalad, 1996). Sustainable competitive advantage is possible as firms effectively utilize these resources with complementary systems (Collis \& Montgomery, 1998; Porter, 1996).

Tehseen and Shilaz (2016) in their study on network competence noted that networking forums are important set-ups for businesses to develop and maintain relationships with different stakeholders to acquire necessary resources. These resources lead to competitive advantage and as a result enhance the firm's performance. The resource based view is then seen to support that entrepreneurial networks facilitate the access and link to resources hence enhances the performance of businesses.

\subsubsection{Dynamic Capability Theory}

The Dynamics Capabilities (DC) view, is drawn from the Resource Based View and helps the business respond to the changing operating environment ((Teece et al., 1997). The ability of firms to integrate, shape and restructure their environments broadens the resource based view (Svare \& Gausdal, 2017). Eisenhardt and Martin (2000) assert that dynamic capabilities are a set of precise and discernible methods that a firm employs including strategy, product development, and alliances (networks). These enhance the firm's competitive advantage as seen by the ability to create, integrate, recombine, and release resources. The authors propose that some dynamic capabilities use external sources or associations that bring new resources into the firm. This is suggested as the value that networking brings to the enterprise when utilized to enrich the firm's performance.

Dynamic capabilities can therefore enhance strategic alliances with entrepreneurial networks to influence the performance of the firm. A research by (Muithya \& Muathe, 2020) revealed that dynamic capabilities alone do not automatically lead to improved performance. However, coupled with networking, a firm can be able to mitigate the changing business operating environments.

\subsubsection{Social Network Theory}

Moreno (1937) introduced the social network theory by stating that individuals in different societies have varied relationships. In a research study on the theoretical analysis of the role of social networks in entrepreneurship, Leyden, Link and Seigel (2014) found that the entrepreneurial social aspect propels an entrepreneur towards business success. These observations also support the entrepreneurship theories that suggest that networking opportunities are naturally formed by the entrepreneurs themselves. Social networks stimulate business growth by reducing operation costs, creating business opportunities, and enhancing the business information or knowledge scope for an entrepreneur.

Subrahmanyam (2019) noted that the social aspect of networking, called 'Social Capital', is a necessary component in the lifecycle of an enterprise. The study concludes that there are gains and resources that are received from social networking. These resources contain knowledge and ideas, business prospects, financial capital access, emotional and moral support, and many more. However, these resources may remain inaccessible if the network is not structured. As discussed by Greve and Salaff (2003), they noted that entrepreneurial networks in different countries are similar. New businesses utilize networks more than established ones, women are more inclined to use their kin more than men, and entrepreneurs access people in their networks to discuss ways to start or operate their businesses. Adamonienè and Astromskiene (2015) noted that through networking, people are able to be social with others while engaging in economic and business pursuits. In this regard, this study seeks to advance the argument that the human element and contact is an important aspect of entrepreneurial networking.

\subsubsection{Social Capital Theory}

The theory of social capital as presented by Bourdieu's (1986) explains that construction of social capital is based on the acknowledgment that capital is not just for profit but that social interactions need to encompass 
other business pursuits in all their forms (Claridge, 2015a). Accordingly, the author viewed social capital as a personal trait, rather than a team effort, derived primarily from one's efforts in gaining a social position and status. This status allows the individual to have clout and influence the group or individual with the resources. Social capital can be viewed also as resources acquired through the familiarity of relationships formed through corporate or formal groupings in institutions or networks (Bourdieu \& Wacquant, 1992). Therefore, social capital once cultivated is innate and is linked to social networks that a person can utilize for enhancing firm performance and growth (Claridge, 2015b).

Fatoki (2011) recommends that to improve social capital, firm owners should always ensure that they have strong network linkages with suppliers, potential and current customers, financiers and government regulatory bodies. Firm owners need to take responsibility to improve their networking through participation in seminars, networking clubs or associations, and also joining trade associations and attending trade fairs.

Okten and Osili (2004) in examining the impact of social capital on the growth of firms, found that social capital has influence on the firm's growth especially through the regular interaction of entrepreneurs. Social capital helps firms access the external environment and tap resources thereby successfully paving the way to new and diverse markets. Association with networks in an external environment gives the firm an opportunity to benchmark its internal environment performance. This was presented in a study by Mask and Bain (2019) who found that social capital is an integral part of entrepreneurial networking and is impactful in different industries and organizations.

The social capital theory supports the advancement that this study is hinged upon, that the performance of the women owned enterprise is linked to the entrepreneurial networks that the entrepreneur engages with. Social capital emboldens the entrepreneur to participate in more networking activities since they have relationships that are strong. Participation in this networks opens up opportunities for the entrepreneur to link with resources that benefit their businesses and overall performance.

\subsubsection{Structural Hole Theory}

The structural hole theory by Burt (1992) focuses on the relationship patterns in a social network, for example, the members of an individual's social network have interconnected relationships. Therefore, a structural hole exists when members of a social network have no connection. This theory postulates that network structure does not predict attitudes or behaviors directly, but it predicts similarity between attitudes and behaviors to encourage formation of beneficial relationships. Thus, it is through these networks that relationships are formed and business people develop ties with other business people. Entrepreneurs thus are drawn to other entrepreneurs in pursuit of common or similar goals. Social networks encourage similarities to develop among people, even in the pursuit of independent interests. As a result, relationships emerge. Therefore, drawing on these relationships, entrepreneurs develop network ties when they engage in networking activities. This helps them access information about resources or tools that improve their business operations with the aim of enhancing their firms' performance.

\subsubsection{Summary of Reviewed Theories}

The table below presented a summary of the theories reviewed on entrepreneurial networks and firm performance. 
Table 1. Summary of theoretical review

\begin{tabular}{|c|c|c|c|}
\hline Theory & Promoters & Argument & Relevance \\
\hline Resource Based View & Penrose (1959) & $\begin{array}{l}\text { Competitive advantage is gained } \\
\text { through an enterprise's effective } \\
\text { use of internal resources }\end{array}$ & $\begin{array}{l}\text { The entrepreneur's, through } \\
\text { networking, gains access to } \\
\text { resources hence firm has } \\
\text { competitive advantage thereby } \\
\text { affecting overall firm } \\
\text { performance }\end{array}$ \\
\hline Dynamic Capabilities & Teece, Pisano, and Shuen (1997) & $\begin{array}{l}\text { Developed to explain RBV; helps } \\
\text { the business respond to the } \\
\text { changing operating environment }\end{array}$ & $\begin{array}{l}\text { Enhance strategic alliances with } \\
\text { entrepreneurial networks to } \\
\text { influence the performance of the } \\
\text { firm }\end{array}$ \\
\hline Social Networking & Moreno and Jennings (1938) & $\begin{array}{l}\text { Individuals in different societies } \\
\text { have varied relationships }\end{array}$ & $\begin{array}{l}\text { Social networks stimulate } \\
\text { business performance }\end{array}$ \\
\hline Social Capital & Bourdieu (1986) & $\begin{array}{l}\text { Individual with Social capital has } \\
\text { power on the group or anyone who } \\
\text { mobilizes the resources. }\end{array}$ & $\begin{array}{l}\text { Individual linked to social } \\
\text { connections utilizes that capital } \\
\text { for advancing the performance } \\
\text { of the enterprise }\end{array}$ \\
\hline Structural Hole & Burt (1992) & $\begin{array}{l}\text { Patterns of relationship in a social } \\
\text { network provide access to diverse } \\
\text { information }\end{array}$ & $\begin{array}{l}\text { Structural holes create } \\
\text { opportunities for members of a } \\
\text { network to obtain information } \\
\text { that influences the firm's } \\
\text { performance }\end{array}$ \\
\hline
\end{tabular}

Source: Author, 2020.

\subsection{Empirical Literature Review}

This section reviews conceptual and empirical literature on entrepreneurial networks and performance of women owned enterprises.

\subsubsection{Firm Performance}

The term performance is used in business to measure the level of output or success of an entity. Performance can be associated with productivity, effectiveness, sustainability and competitiveness. Economically, the firm's performance includes the ability to access and allocate resources optimally while profiting and justifying the risk taken and the interest gained, for future sustainability (Ciurea \& Demyen, 2015; Musau, Muathe \& Mwangi, 2018; Kiveu, Namusonge, \& Muathe, 2019).

According to Fatoki (2011), many research studies have narrowly focused on one dimension of performance, either financial or non-financial. The author perceives that this could lead to a misleading descriptive and normative theory building and therefore recommends that research should use multiple performance measurements.

Studies that feature the non-financial aspects that influence the performance of women owned enterprises discuss factors such as demographics, motivation of the entrepreneur, sociological aspects among others. Julius (2017) noted that education levels, domestic obligations, government policies \& regulations and competition influences the outcome of performance of women owned enterprises. In another study, economic, socio-cultural, legal and administrative factors are also listed as non-financial factors that influence the performance of women enterprises (Wube, 2010). In a different research, the authors used the following variables as measures of non-financial factors that influence performance: Human Capital (HC); Entrepreneurial Orientation (EO); goals and motivations; industry, Enterprise and Industry characteristics; Legal and Administrative Factors (LAFs); Economic Factors (EFs); Socio-Cultural Factors (SCFs); and Opportunity Recognition (OR) (Hasan \& Almubarak, 2016).

According to Mwangi, Makau and Kosimbei (2014), financial factors that influence the performance of businesses contribute more significantly to the outcome of the performance measurement, i.e. Return on Equity (ROE), investment gains made by investors, and Return on Assets (ROA), and the organization's ability to utilize its assets. Additionally, market share and the size of firm are also stated as organizational factors that influence the financial performance of an enterprise (Saad \& Zhengge, 2016). A different study carried out in Kenya concluded that corporate governance; human capital had a major influence on the financial performance of enterprises (Nakhaima, 2016). 


\subsubsection{Entrepreneurial Networking}

Studies investigating entrepreneurial networks have increased in entrepreneurial research (Kariuki, 2015; Kaberia \& Muathe, 2019; McGrath et al., 2019). The areas of interest are in networking benefits to performance of enterprises, effects of networking to women owned enterprises, with emphasis on the value of networking to entrepreneurial activities world over.

Entrepreneurial networking is an area of study that has been researched widely because of the value that networking lends to entrepreneurs world over. Networking applies to business start-ups and incubators (McGrath et al., 2019; Shih \& Aaboen, 2019), to small and medium enterprises (SMEs) (Das \& Goswami, 2019; Ojotu et al., 2019), and is greatly evidenced among large corporations (Buckley \& Prashantham, 2016; Veleva \& Bodkin, 2018).

Chiesi (2018) identified Entrepreneurial Networks (EN) as relationships that emerge from entrepreneurial undertakings. In their normal activities, entrepreneurs meet other entrepreneurs or stakeholders that and form synergies that benefit the functions of their business. The importance of EN is underscored by a study by Kariuki (2015) which concluded that business networking plays an important role on the performance of women owned enterprises in Kenya. The structure of entrepreneurial network supports various relationships and significantly affects the growth of businesses.

Das and Goswami (2019) in their study have argued that in addition to the network structure, the type of network and its demographic characteristics also influence firm performance.

Ojutu et al. (2019) highlights three dimensions of networking that influence performance. The study adds to previous research by suggesting that the structure of the networks has an effect on performance. It also discusses network governance and network content as other aspects that influence the performance of small and medium enterprises. Network governance has to do with the mechanisms that facilitate resource exchange within networks. It demands trust, respect, and reciprocity. This concept ties in with the concept of relations within networks as proposed by (Kariuki, 2015).

Cooperation among network members helps those who have limited capital resources and time to engage in market research (Malecki \& Tootle, 1996). However, most entrepreneurs run their business trying to gain competitive advantage rather than forming alliances with other similar businesses through cooperation (Martin \& Stiefelmeyer, 2009). Consequently, the process of how firms develop and advance mutually beneficial entrepreneurial networks justifies increasing more research work on the benefits of intentional networking efforts by the entrepreneur (Day \& Montgomery, 1999; Doris, 2016).

Studies have also shown that entrepreneurial networks contribute positively to the performance of an enterprise. Adomako et al. (2018) found that under conditions of increased use of social and business networking capabilities, the effectiveness of entrepreneurial alertness encourages new growth in an enterprise. For this study, the structure, demographics and type of entrepreneurial networks will be studied to establish how these affect the performance of women owned enterprises, particularly in Kenya.

\subsubsection{Dynamic Capabilities}

Dynamic capabilities are useful to managers (entrepreneurs) in defining their organizational and strategic goals with the aim of acquiring or discharging resources, assimilating and reorganizing these resources to generate value addition strategies (Grant, 1996; Pisano, 1994). Dynamic capabilities are the firm's tool towards achieving competitive advantage depending on the configuration of the available resources (Teece et al., 1997).

Eisenhardt and Martin (2000) termed dynamic capabilities as processes that cause markets to change through utilization of the available resources within firms. Dynamic capabilities act as the organizational and strategic routines by which firms achieve new resource configurations that influence the existence of markets.

In this study, dynamic capabilities are proposed as the mediating variable to demonstrates the relationship between entrepreneurial networks and performance of women owned enterprises. The study recommends that dynamic capabilities within an organization are influenced by the networks in which the entrepreneur is a participant. This in turn allows the entrepreneur, as the manager, to be able to reconfigure their internal resources to monitor the performance of the firm as it responds to the changing business operating environment.

\subsubsection{Business Operating Environment}

Roxas, Chadee and Erwee (2012) identified the substantial factors for the regulatory environment in which businesses operate as being: a judicial system that not corrupt, is independent and effective; a law enforcement that is effective in controlling crime; an equitable and efficient tax regime; a stable political climate; and 
governance structures that are corruption-free and deliver basic government amenities. These factors provide regulatory structures that governments should advocate to ensure a conducive environment for development and growth of businesses.

The business operating environment influences the performance of the enterprise. A change in the environment presents for one enterprise an opportunity and for another a threat (Gohil, 2018). The study continues to state that the business operating environment is a summation of the firm's macro and micro environmental factors that influence the business e.g. customers, technology, finances, employees, regulations, supply and demand, among others. The link between entrepreneurial networking and performance of the firm hence is advanced by the environment that the business operates.

Todeva's (2011) research demonstrated that entrepreneurial networks interconnect the business operating environment with various stakeholders. These connections create opportunities for resources that enrich the direct dependence of the firm's performance on entrepreneurial networks. This study examines this relationship with the view to add to the knowledge base on improving performance of women owned enterprises. Mozumdar et al. (2020) noted that the operating business environment affects the performance women owned enterprises, thus the ties that women have with their entrepreneurial networks influences the firm's performance.

Gohil (2018) stated that technological factors can either hurt or enhance the business opportunities. This in turn has an effect on how the business performs. The regulatory framework in which a business operates in can greatly affect the outcome of the firm's performance depending on the government and policies set out. Punitive tax measures or licensing prohibitions can deter growth of businesses. Alternately, favorable tax regimes and loan incentives can facilitate the growth of businesses (Mukherjee, 2015). This study encompasses the moderating effect of the business operating environment the link between entrepreneurial networking and women owned enterprises performance.

\subsubsection{Women Owned Enterprises}

According to Coughlin and Thomas (2003), women owned enterprises dates back as far as the World War II when women in western labor markets ventured into the realms of the workplace and business world in a bid to seek financial freedom and self-sufficiency. Additionally, in many developing countries, manufacturing had been on the rise leading to modernization. As in industrialized nations, change occurred at an accelerated pace. During this period of volatility and instability, ambitious, energetic, and creative women seized the initiative to start their own enterprises. As a result, women became a dynamic force in the growth of emergent and newly industrialized and developing economies around the world (Coughlin \& Thomas, 2003).

Women entrepreneurs practice entrepreneurship within the definitions of exploiting market opportunities, demonstrating initiative and creative thinking. They are able to organize economic and social combinations that make resources and opportunities convert to beneficial outcomes while taking risks and accepting occasional failure as part of entrepreneurial growth. Women in entrepreneurship is a concept that will guide this study in establishing the how the performance of their enterprises is linked to entrepreneurial networking.

\subsubsection{Entrepreneurial Networking and Performance of Enterprises}

Entrepreneurial networking has been studied by scholars to show its influence on firm performance. Das and Goswami (2019) established that the density and distinctive levels of networks had a positive impact on the performance of the firm. This was evidenced in the level of participation in the networks and the quality of resources and information obtained from networking. Networking provides the entrepreneur with important contacts, collaborations, and partnerships which eventually result in new opportunities for the business (Wallace, 2006; Edwards, Edwards, \& Benzel, 2007).

Agbim (2018) wanted to view the influence of networking on performance of the overall business and concluded that there are both financial and non-financial performance outcomes achieved from networking. Moreover, Nyangarika (2016) assessed the role of networking to small and medium enterprises and determined that it contributes towards profitability of the firm, a financial outcome. The researchers accessed networking from an information and communication technology (ICT) angle that revealed that its useful in market accessibility and productivity. The concept of networking in the said study was narrowed to information communication technology (ICT).

Leskinen (2011) viewed entrepreneurial success as that which is brought about by entrepreneurial networking where network members work together to achieve a beneficial outcome for their business performance. In most networks, a significant test of success is sales turnover, employment creation, efficient or improved productivity that leads to profit, lower costs, and return on investment. The authors further ventured into measures that female 
entrepreneurs use to improve the performance of their businesses and found that they were personal and intimate, e.g. peer support, encouragement, and bonding. This creates new partnerships and opportunities to learn new entrepreneurship experiences. Improved performance for the female entrepreneur means an enhanced lifestyle, too.

\subsubsection{Entrepreneurial Networking, Dynamic Capabilities and Performance of Enterprises}

Dynamic capabilities can be applied by small firms to achieve sustainable performance in otherwise competitive business environments (Abbas et al., 2019). These authors in this study proposed the mediating role of dynamic capabilities between networking and the performance of small enterprises. They concluded that firms that were highly entrepreneurial utilized business networks and dynamic capabilities proficiently to achieve their sustainable performance. The study was conducted specific to small enterprises in the surgical manufacturing sector in Pakistan (Abbas et al., 2019). The researchers, therefore, proposed future research models to consider the age of the firm as a moderating variable and small and medium enterprises' learning orientation as a mediating variable in order to develop more precise conclusions. Another recommendation was the adoption of a cross-sectional research design for data collection and research determination. This would add value in comparing different sectors/industries authentication of the value of dynamic capabilities role between networking and performance (Abbas et al., 2019). Future studies could use the longitudinal design to test this proposed model and research direction. This context can contribute to the academic literature concerning performance, networking and dynamic capabilities of firms in other cultural or country contexts to validate the applicability of the research findings.

Bai et al. (2016) argue that performance innovation results from networking capability and has a positive influence on the provision of broadened business knowledge essential to innovation. Authors Zheng, Zhang and $\mathrm{Du}$ (2011) assert that businesses ought to employ both internal and external resources to confront the volatile business environments. The authors in this study investigated the mediating role of knowledge acquisition between networking and innovation performance of the firm. Dynamic capabilities emphasize a firm's constant pursuit to increase and reconfigure their resource bases through knowledge acquisition. Networking facilitates the firm's dynamic capabilities to access the external resources thereby increasing the firm's knowledge and improving its performance.

Dynamic capabilities and entrepreneurial networking expose the entrepreneur and their business to knowledge on innovation that helps the business compete in environments that sometimes can be hostile or steeply competitive. Empirical studies hence suggest that the firm's performance can be enhanced by factoring the concepts relational concepts of dynamic capabilities and entrepreneurial networking (Zheng, Zhang \& Du, 2011). In this study, dynamic capabilities, through reconfiguration of the internal resources and knowledge acquisition, are introduced as the mediating variable between entrepreneurial networking and firm performance. Future studies should be carried out to show this relationship especially in defining the internal resources that need to be reconfigured and what knowledge the firm requires so as to ensure the firm's optimal performance through networking.

\subsubsection{Entrepreneurial Networking, Business Operating Environment and Performance of Enterprises}

The relationship between the operating environment and the performance of firms should be an area of interest in studies on women entrepreneurship. Wanjiru, Muathe, and Kinyua-Njuguna, (2019) conducted a study focusing on manufacturing firms to establish the role of this relationship and found it significant. The study recommended that governments ought to review regulations to have favourable tax regimes and fiscal policies that encourage borrowing so that manufacturing firms' performance can be enhanced. The study used the operating environment as a moderating variable on the relationship between firm performance and corporate strategy. This study proposes a research on the moderating effect of the business operating environment on the relationship between entrepreneurial networks and firm performance. This study can borrow from the Wanjiru et al. (2019) contextual framework to study this relationship among women owned enterprises in the different industry contexts.

\subsection{Issues Arising from the Conceptual and Empirical Discussions}

Empirical studies have indicated that entrepreneurial networking is an important component of the firm's performance. Yet, many businesses do not take advantage of these networks to enhance the performance of their businesses. More so, women owned enterprises have shown lackluster uptake to participation in these entrepreneurial related networks. In addition, the studies reviewed assumed a direct link between entrepreneurial networks and performance and thus ignored other variables like dynamic capability and the Business Operating Environment that could affect the nature of the relationship. 
The concept of performance should be measured using both financial and Non-Financial Measures. Future studies should give a more holistic approach by incorporating dynamic capabilities as a mediating variable and the business operating environment as a moderating variable. The purpose of the dynamic capabilities as a mediating variable is to explain the link between entrepreneurial networking and firm performance while the moderating variable of the Business Operating environment is to establish the strength of the relationship between entrepreneurial networks and performance of women owned enterprises. The measures adopted for this study will be the effect of technology and the regulatory framework as the factors affecting the business environment.

\section{Proposed Conceptual Framework}

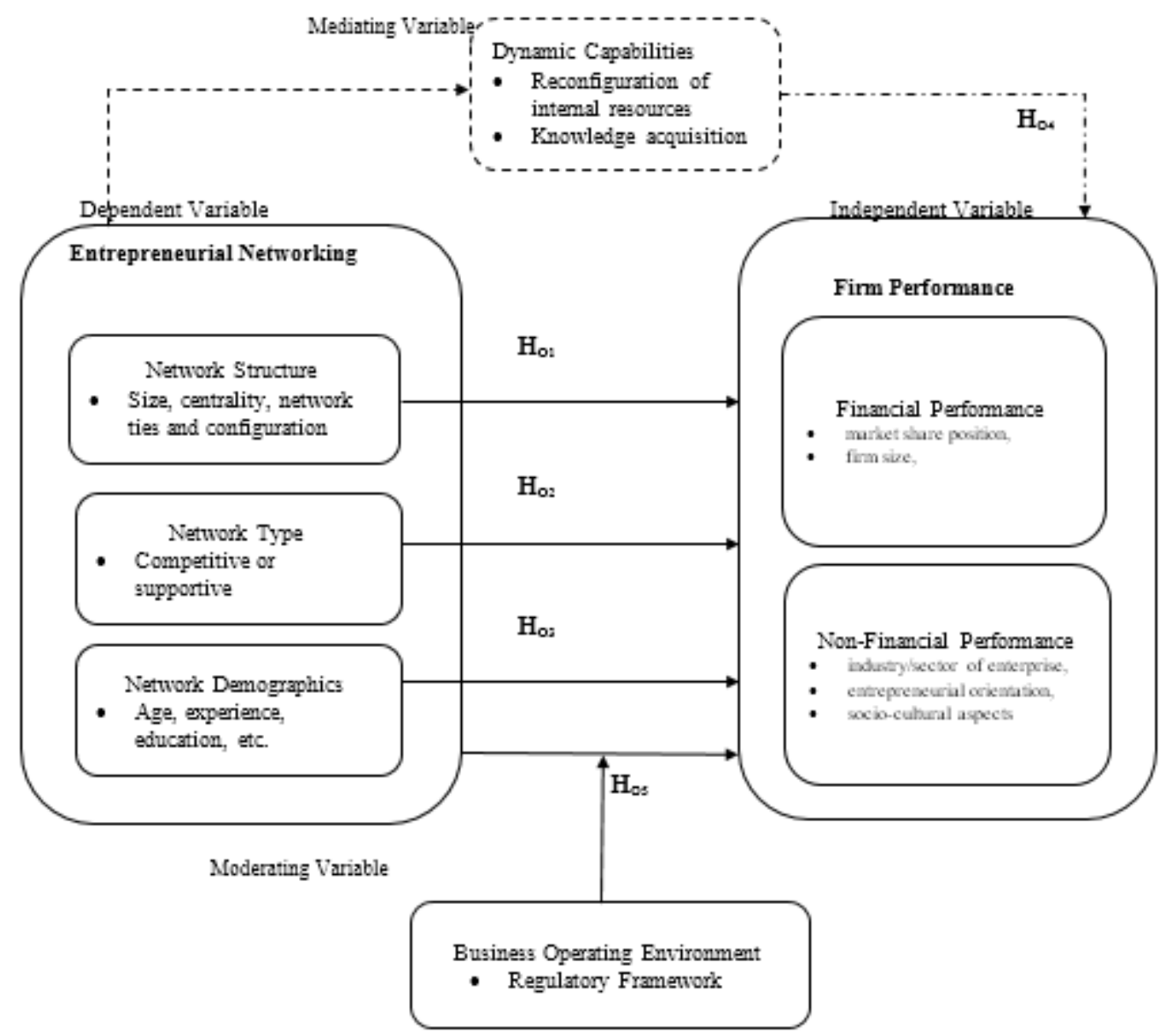

Figure 2. Conceptual framework

Source: Author (2020)

\subsection{Prepositions}

The proposed conceptual framework is drawn from the gaps identified in the study. It represents the study relationship between the constructs of entrepreneurial networking and the performance of women owned enterprises while factoring in the mediating effect of Dynamic Capabilities and the moderating variable of the business operating environment. Entrepreneurial networking is the independent variable while performance is the dependent variable. The following hypotheses can be drawn from the conceptual framework:

$\mathrm{H}_{\mathrm{O} 1}$ : Network structure has a no significant effect on the performance of women owned enterprises.

$\mathrm{H}_{\mathrm{O} 2}$ : Network type has a no significant effect on the performance of women owned enterprises.

$\mathrm{H}_{\mathrm{O} 3}$ : Network demography has a no significant effect on the performance of women enterprises.

$\mathrm{H}_{\mathrm{O} 4}$ : Dynamic Capabilities do not have any significant mediating effect relationship between entrepreneurial networking and the performance of women owned enterprises

$\mathrm{H}_{05}$ : Business operating environment has no significant moderating effect on the relationship between 
entrepreneurial networking and the performance of women owned enterprises.

\section{Proposed Methodology}

Several research studies (Tomos et al., 2015; Yadav \& Unni, 2016; Guetterman \& Fetters, 2018) have argued that when carrying out a study on women entrepreneurship, it is prudent to apply a mixed methodology which promotes the use of various data collection methods like interviews, case studies, questionnaires and use of secondary data.

The mixed methodology design has been used in a study by Kanini and Muathe (2019). In the study, it was concluded that a research design that applies explanatory non-experimental and descriptive research designs to analyze the constructs, gives a better outcome as compared to a study using a single research design.

From the reviewed literature most studies used descriptive survey design while others used explanatory design, however a single design has a limitation of analyzing most issues on a study. For example, descriptive doesn't test the cause-effect relationship while explanatory design doesn't describe the nature of the phenomenon of the study. This study, therefore, recommends a mixed research design composed of explanatory non-experimental and descriptive research designs.

In support of more inclusive research methodology (Yadav \& Unni, 2016) offered that research on women entrepreneurship should adopt a positivist research paradigm where empirical studies reveal a comparison of the women to men gender. The authors propose that a constructionist approach to study women entrepreneurship processes would give more objectivity and understanding of a women entrepreneurs. A constructionist approach is proposed since the study seeks to add knowledge in the women entrepreneurship paradigm.

\section{Conclusion and Direction for Future Research}

The empirical evidence obtained in this study revealed that there are convergent views that entrepreneurial networks have affect performance of women entrepreneurship. Therefore, those women owned enterprises that focus on enhancing the business network circles are likely to do better than those not participating in business networks. This is because, as this study has shown, a lot of business ideas are discussed in those networks like the effect of the operating business environment particularly the regulatory framework, marketing, sources of business financing among others. Hence future research should establish how the entrepreneurial networks can help businesses to enhance competitive advantage and thus the performance of women owned enterprises.

Empirical studies also revealed that the direct link between entrepreneurial networking and performance is indicated by such outcomes as profitability, new business opportunities, access to new markets, increased productivity, among others. This study proposes that this direct relationship of networking and performance should advance future studies in women entrepreneurship. This will add knowledge and the call into how women can use networking to promote the performance of their ventures from commonly small and medium women enterprises to the next profitability and productivity levels (Kariuki, 2015). The research should be aimed at addressing the gap on growth of women entrepreneurship/enterprises to promote economic growth.

Literature on the relationship between firm performance and entrepreneurial networking using the moderating effect of the business operating environment is not readily available. This study hence proposes to add to this knowledge gap in future research to postulate the regulatory environment of business influences the relationship outcomes between networking and firm performance.

From the forgoing discussion of this study, it is necessary to do more research to illustrate the link between entrepreneurial networking and the performance of women owned enterprises to meet the objective of proposing a conceptual framework to discuss the constructs of the study. This study proposes to bridge the gap by including the business operating environment as a moderator and dynamic capabilities as a mediating variable.

\section{Limitation of the Study}

This study was a desk-top research and used secondary data to establish the effect of and give insight on entrepreneurial networks on performance of women owned enterprises. However, further research is recommended and can be conducted using more detailed data collection methods, like questionnaires and interviews, to consider primary data and to build more literature to the already existing secondary data.

\section{References}

Adamonienè, R., \& Astromskienè, A. (2015). Peculiarities of Entrepreneurial Socialization Expression. Procedia - Social and Behavioral Sciences, 213, 890-895. https://doi.org/10.1016/j.sbspro.2015.11.501

Adomako, S., Danso, A., Boso, N., \& Narteh, B. (2018). Entrepreneurial Alertness and New Venture 
Performance: Facilitating Roles of Networking Capability. International Small Business Journal, 36(5), 453-472. https://doi.org/10.1177/0266242617747667

Agbim, K. C. (2018). Social Networking and the Family Business Performance: A Conceptual Consideration.

Amit, R., \& Schoemaker, P. (1993). Strategic Assets and Organizational Rent. Strategic Management Journal Strategic Management Journal, 14, 33-46. https://doi.org/10.1002/smj.4250140105

Bai, W., Lind, C. H., \& Johanson, M. (2016). The Performance of International Returnee Ventures: The Role of Networking Capability and the Usefulness of International Business knowledge. Entrepreneurship and Regional Development, 2(9/10), 657-680. https://doi.org/10.1080/08985626.2016.1234003

Bain, J. S. (1968). Industrial organization. New York: Wiley

Buckley, P. J., \& Prashantham, S. (2016). Global Inter-firm Networks: The Division of Entrepreneurial Labor Between MNEs and SMEs. Academy of Management Perspectives, 30(1), 40-58. https://doi.org/10.5465/amp.2013.0144

Ciurea, J., \& Demyen, S. (2015). Relevance of Turnover for the Performance Analysis of an Enterprise.

Claridge, T. (2015a). Bourdieu on Social Capital - Theory of Capital. Retrieved from https://www.socialcapitalresearch.com/bourdieu-on-social-capital-theory-of-capital/

Claridge, T. (2015b). Bourdieu on Social Capital - Theory of Capital. Retrieved from https://www.socialcapitalresearch.com/bourdieu-on-social-capital-theory-of-capital/

Collis, D., \& Montgomery, C. (1998). Creating Corporate Advantage. Harvard Business Review, 76(3), 70-83.

Conner, K. R., \& Prahalad, C. K. (1996) A Resource-Based Theory of the Firm: Knowledge vs. Opportunism. Organization Science, 7, 477-501. http://dx.doi.org/10.1287/orsc.7.5.477

Coughlin, J., \& Thomas, A. (2003). The Rise of Women Entrepreneurs: People, Processes, and Global Trends. Choice Reviews Online, 40(10), 40-5888. https://doi.org/10.5860/CHOICE.40-5888

Das, M., \& Goswami, N. (2019). Effect of Entrepreneurial Networks on Small Firm Performance in Kamrup, A District of Assam. Journal of Global Entrepreneurship Research, 9(1), 7. https://doi.org/10.1186/s40497-018-0122-6

Denzin, N. K. (2017). The research act: A Theoretical Introduction to Sociological Methods. Transaction publishers. https://doi.org/10.4324/9781315134543

Doris, N. (2016). Factors Influencing the Performance of Female Owned Enterprises: A Case of Businesses in the Central Business District of Nairobi, Kenya.

Edwards, P., Edwards, S., \& Benzel, R. (2007). Teeming up: The Small-Business Guide to Collaborating with others to Boost your Earnings and Expand your Horizons. New York: G.P. Putnam's Sons.

Eisenhardt, K. M., \& Martin, J. A. (2000). Dynamic Capabilities: What Are They? Strategic Management Journal, 21 , $1105-1121$. https://doi.org/10.1002/1097-0266(200010/11)21:10/11<1105::AID-SMJ133>3.0.CO;2-E

Fatoki, O. O. (2011). The Impact of Human, Social and Financial Capital on the Performance of Small and Medium-Sized Enterprises (SMEs) in South Africa. Journal of Social Sciences, 29(3), 193-204. https://doi.org/10.1080/09718923.2011.11892970

Gohil, S. (2018). Business Environment - Conceptual Framework and Policies. http://doi.org/10.21276/2455-295X.

Grant, R. M. (1996). Toward a Knowledge Based Theory of the Firm. Strategic Management Journal, 17, 109-122. https://doi.org/10.1002/smj.4250171110

Greve, A., \& Salaff, J. W. (2003). Social Networks and Entrepreneurship. Entrepreneurship Theory and Practice, 28(1), 1-22. https://doi.org/10.1111/1540-8520.00029

Guetterman, T. C., \& Fetters, M. D. (2018). Two Methodological Approaches to the Integration of Mixed Methods and Case Study Designs: A Systematic Review. American Behavioral Scientist, 62(7), 900-918. https://doi.org/10.1177/0002764218772641

Hasan, F. S. M. A., \& Almubarak, M. M. S. (2016). Factors Influencing Women Entrepreneurs' Performance in SMEs. World Journal of Entrepreneurship, Management and Sustainable Development, 12(2), 82-101. https://doi.org/10.1108/WJEMSD-09-2015-0037 
Julius, O. C. (2017). Non-financial Factors Influencing Performance of Women Owned Enterprises in Kenya: A Case Study of Women Owned Enterprises in Kisauni Sub-County.

Kanini, K. S., \& Muathe, S. M. A. (2019). Nexus between Social Capital and Firm Performance: A Critical Literature Review and Research Agenda. International Journal of Business and Management, 14(8), 70-82. https://doi.org/10.5539/ijbm.v14n8p70

Kariuki, J. W. (2015). Perceived Role of Business Networking on the Performance of Women Owned Enterprises in Kenya: A Case Study of Kenya Association of Women Business Owners.

Kiveu, M. N., Namusonge, M., \& Muathe, S., (2019). Effect of Innovation on Firm Competitiveness: The case of Manufacturing SMEs in Nairobi County, Kenya. International Journal of Business Innovation and Research, 18(3), 307-327. https://doi.org/10.1504/IJBIR.2019.098251

Lange, T., Ottens, M., \& Taylor, A. (2000). SMEs and Barriers to Skills Development: A Scottish Perspective", Journal of European Industrial Training, 24(1), 5-11. https://doi.org/10.1108/03090590010308219

Leskinen, R. (2011). Success in the Female Entrepreneurial Networking Process. Annals of Innovation \& Entrepreneurship, 2(1), 6002. https://doi.org/10.3402/aie.v2i1.6000

Leyden, D. P., Link, A. N., \& Siegel, D. S. (2014). A theoretical analysis of the role of social networks in entrepreneurship. Research Policy, 43(7), 1157-1163. https://doi.org/10.1016/j.respol.2014.04.010

Liu, L., Timothy, V., \& Gao, Y. (2010). A Review of Approaches of Resource-based Empirical Research in Banking. The International Journal of Applied Economics and Finance, 4, 230-241. http://doi.org/10.3923/ijaef.2010.230.241

McGrath, H., Medlin, C. J., \& O'Toole, T. (2019). A Process-Based Model of Network Capability Development by a Start-up Firm. Industrial Marketing Management, 80, 214-227. https://doi.org/10.1016/j.indmarman.2017.11.011

McQuaker, S. (2007). Relational Concept Knowledge in a Social Network. https://doi.org/10.22215/etd/2007-07733

Mozumdar, L., Hagelaar, G., Velde, G., \& Omta, O. (2020). Determinants of the Business Performance of Women Entrepreneurs in the Developing World Context. https://doi.org/10.3390/j3020017

Muathe, S. M. A. (2010). The Determinants of Adoption of Information and Communication Technology by Small and Medium Enterprises within the Health Sector in Nairobi, Kenya. Unpublished PhD Thesis, Kenyatta University, Kenya.

Muathe, S. M. A., \& Muraguri-Makau, C. W. (2020). Entrepreneurial Spirit: Acceptance and Adoption of E-Commerce in the Health Sector in Kenya. International Journal of Business, Economics and Management Works, 7(8), 8-14.

Muathe, S. M., Wawire, N. W., \& Ofafa, G. A. (2013). An Empirical Study on the Relationship Between Organizational Factors and Adoption of ICT Among Health Related SMEs in Nairobi, Kenya. International Journal of Arts, 2(3), 1-16

Muithya, V., \& Muathe, S. (2020). Dynamic Capabilities and Performance in the Context of Microfinance Institutions in Kenya: An Exploratory Study. International Journal of Business, Economics and Management Works, 7(8), 15-29.

Mukherjee, S. (2015). Business Environment Types (External Micro and External Macro). Economics Discussion. Retrieved from https://www.economicsdiscussion.net/business-environment/business-environment-types-external-micro-an d-external-macro/10095

Mulu-Mutuku, M. W., Odero-Wanga, D., \& Ali-Olubandwa, A. (2015). Female Entrepreneurship in Kenya: How do Female Micro-Entrepreneurs Learn to be Entrepreneurial? Case Studies in Business and Management, 2(1), 1. https://doi.org/10.5296/csbm.v2i1.6809

Musau, S., Muathe, S., \& Mwangi, L. (2018). Financial Inclusion, Bank Competitiveness and Credit Risk of Commercial Banks in Kenya. International Journal of Financial Research, 9(1), 203-218. https://doi.org/10.5430/ijfr.v9n1p203

Mwangi, L. W., Makau, M. S., \& Kosimbei, G. (2014). Relationship between Capital Structure and Performance of Non-Financial Companies Listed in the Nairobi Securities Exchange, Kenya. Global Journal of 
Contemporary Research in Accounting, Auditing and Business, 1(2), 72-90.

Nakhaima, F. K. (2016). Factors that Affect Financial Performance of Small and Medium Enterprises in Kenya.

Nyangarika, A. (2016). Impact of Networking on Performance of Small and Medium Enterprises in Tanzania. Retrieved from http://repository.businessinsightz.org/handle/20.500.12018/553

Ojotu, E. L., Tersoo, T. J., \& Kenneth, O. M. (2019). Effect of Networking on Performance of Small and Medium Scale Enterprises in Benue State, Nigeria. South Asian Research Journal of Business and Management, 1(4), 168-177. https://doi.org/10.36346/sarjbm.2019.v01i04.002

Oke, D. F. (2013). The Effect of Social Network on Women Entrepreneurs in Nigeria: A Case study of Ado-Ekiti Small Scale Enterprise.

Okten, C., \& Osili, U. O. (2004). Social Networks and Credit Access in Indonesia. World Development, 32(7), 1225-1246. https://doi.org/10.1016/j.worlddev.2004.01.012

Pisano, G. P. (1994). Knowledge, Integration, and the Locus of Learning: An Empirical Analysis of Process Development. Strategic Management Journal, 15, 85-100. https://doi.org/10.1002/smj.4250150907

Porter, M. E. (1980). Competitive Strategy: Techniques for Analyzing Industries and Competitors. New York: Free Press.

Porter, M. E. (1985). Competitive advantage: Creating and Sustaining Superior Performance. Free Press; Collier Macmillan.

Porter, M. E. (1996). What is Strategy? Harvard Business Review, 61-78.

Roxas, B., Chadee, D., \& Erwee, R. (2012). Effects of Rule of Law on Firm Performance in South Africa. European Business Review, 24, 478-492. https://doi.org/10.1108/09555341211254544

Saad, M., \& Zhengge, T. (2016). The Impact of Organizational Factors on Financial Performance: Building a Theoretical Model. Journal of International Business Research and Marketing, 2(7), 51-56. https://doi.org/10.18775/ijmsba.1849-5664-5419.2014.27.1005

Shih, T., \& Aaboen, L. (2019). The Network Mediation of an Incubator: How does it Enable or Constrain the Development of Incubator Firms' Business Networks? Industrial Marketing Management, 80, 126-138. https://doi.org/10.1016/j.indmarman.2017.12.002

Skokic, V. (2015). Motivations and Benefits of Entrepreneurial Network Formation. International Journal of Business and Management, 10(9), 109. https://doi.org/10.5539/ijbm.v10n9p109

Soni, P. (2015). The Theory of the Growth of the Firm: A Theoretical Review of the Resource Based View.

Subrahmanyam, S. (2019). Social Networking for Entrepreneurship. International Journal of Commerce and Management Research, 5(1), 117-122.

Svare, H., \& Gausdal, A. H. (2017). Dynamic Capabilities and Network Benefits. Journal of Entrepreneurship, Management and Innovation, 13(1), 117-146. https://doi.org/10.7341/20171315

Tawane, I. A., \& Muathe, S. M. (2019). Strategy Implementation and Growth of Small and Medium Enterprises in Garissa County, Kenya. Eastern Africa Journal of Contemporary Research, 1(2), 79-88.

Teece, D., Pisano, G., \& Shuen, A. (1997). Dynamic Capabilities and Strategic Management. Strategic Management Journal, 18(7), 509-533. https://doi.org/10.1002/(SICI)1097-0266(199708)18:7<509::AID-SMJ882>3.0.CO;2-Z

Tehseen, S., \& Sajilan, S. (2016). Network Competence Based on Resource-Based View and Resource Dependence Theory. International Journal of Trade and Global Markets, 9(1), 60-82. https://doi.org/10.1504/IJTGM.2016.074138

Todeva, E. (2011). Entrepreneurial Networks. Encyclopedia of Social Networks. https://doi.org/10.4135/9781412994170.n106

Tomos, F., Djebarni, R., Rogers, A., Thomas, A., Clark, A., \& Balan, C. (2015). Mixed Research Methods: Former and new Trends in Women Entrepreneurship Research.

Trizer, M. (2019). Kenya Population and Housing Census Results. Kenya National Bureau of Statistics. Retrieved from https://www.knbs.or.ke/?p=5621

Veleva, V., \& Bodkin, G. (2018). Corporate-entrepreneur Collaborations to Advance a Circular Economy. Journal of Cleaner Production, 188, 20-37. https://doi.org/10.1016/j.jclepro.2018.03.196 
Wallace, E. (2006). Fares to Friends: How to Develop Outstanding Business Relationships. USA: The Relational Capital Group.

Wanjiru, A. I., Muathe, S. M., \& Kinyua-Njuguna, J. W. (2019). Moderating Effect of External Operating Environment on the Relationship between Corporate Strategies and Performance of Manufacturing Firms in Nairobi City County, Kenya. European Journal of Business and Management, 11(14), 34-44.

Wernerfelt, B. (1984). A Resource Based View of the Firm. Strategic Management Journal, 5, 171-180. https://doi.org/10.1002/smj.4250050207

Wernerfelt, B. (1995). The Resource Based View of the Firm: Ten Years After. Strategic Management Journal, 16, 171-174. https://doi.org/10.1002/smj.4250160303

Wube, M. C. (2010). Factors Affecting the Performance of Women Entrepreneurs in Micro and Small Enterprises. Unpublished MA Thesis, Bahir Dar University.

Yadav, V., \& Unni, J. (2016). Women entrepreneurship: Research Review and Future Directions. Journal of Global Entrepreneurship Research, 6(1), 12. https://doi.org/10.1186/s40497-016-0055-x

Zheng, S., Zhang, W. \& Du, J. (2011), "Knowledge Based Dynamic Capabilities and Innovation in Networked Environments. Journal of Knowledge Management, 15(6), 1035-1051. https://doi.org/10.1108/13673271111179352

\section{Copyrights}

Copyright for this article is retained by the author(s), with first publication rights granted to the journal.

This is an open-access article distributed under the terms and conditions of the Creative Commons Attribution license (http://creativecommons.org/licenses/by/4.0/). 